\title{
Web of Human Relationships in Select Novels of J. M. Coetzee: A Literature Review
}

\author{
Severine Pinto $^{1} \&$ A. Lourdusamy ${ }^{2}$ \\ ${ }^{1}$ Research Scholar, College of Science and Humanities, Srinivas University, India \\ Assistant Professor, St Aloysius College (autonomous), Mangaluru-575003, India \\ Orcid ID: 0000-0001-6690-7682, Email: severine_pinto@staloysius.edu.in \\ ${ }^{2}$ Research Professor, Srinivas University, Mangaluru-575003 \\ Orcid ID: 0000-0002-9011-6212, Email: swamysac@gmail.com
}

Area/Section: Humanities.

Type of the Paper: Review-based Analytical Research.

Type of Review: Peer Reviewed as per $|\mathrm{C}| \mathrm{O}|\mathrm{P}| \mathrm{E} \mid$ guidance.

Indexed in: OpenAIRE.

DOI: https://doi.org/10.5281/zenodo.5527520

Google Scholar Citation: $\underline{\text { IJMTS }}$

\section{How to Cite this Paper:}

Severine Pinto, \& Lourdusamy, A., (2021). Web of Human Relationships in Select Novels of J.M. Coetzee: A Literature Review. International Journal of Management, Technology, and Social Sciences (IJMTS), 6(2), 147-155. DOI: https://doi.org/10.5281/zenodo.5527520

International Journal of Management, Technology, and Social Sciences (IJMTS) A Refereed International Journal of Srinivas University, India.

CrossRef DOI: https://doi.org/10.47992/IJMTS.2581.6012.0160

(C) With Author.

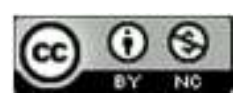

This work is licensed under a Creative Commons Attribution-Non-Commercial 4.0 International License subject to proper citation to the publication source of the work.

Disclaimer: The scholarly papers as reviewed and published by the Srinivas Publications (S.P.), India are the views and opinions of their respective authors and are not the views or opinions of the SP. The SP disclaims of any harm or loss caused due to the published content to any party. 


\author{
Severine Pinto $^{1} \&$ A. Lourdusamy ${ }^{2}$ \\ ${ }^{1}$ Research Scholar, College of Science and Humanities, Srinivas University, India \\ Assistant Professor, St Aloysius College (autonomous), Mangaluru-575003, India \\ Orcid ID: 0000-0001-6690-7682, Email: severine_pinto@staloysius.edu.in \\ ${ }^{2}$ Research Professor, Srinivas University, Mangaluru-575003 \\ Orcid ID: 0000-0002-9011-6212, Email: swamysac@ gmail.com
}

\begin{abstract}
Purpose: The depiction of the problems of conflicts and contradictions and graphical portrayal of the web of human relationship among people of varied races in South African society by Coetzee has been identified as the focus of the study. The British rule had an impact on South Africa that comprised the native South Africans or black race, Afrikaners or the white South Africans and the white people of colonial authority. The research has reviewed related research articles, books and research theses done on the novels of J.M. Coetzee to consolidate the data on the portrayal of the web of human relationship among people of varied races in South Africa. A close reading of select novels of Coetzee also reveals the effects of racism and colonial oppression. More importantly, his writings transcend political, geographical and social boundaries to achieve universal significance. The study of related literature in the works of Coetzee further discloses his ability not only to delineate local situations and characters but to infuse them with universal ideology and characteristics of his mission as well. However, the study to achieve research focus has been confined to the web of human relationships. His use of the country's apartheid system and its post-apartheid transition to represent the bareness and desolation of the human state has also been brought under the discussion. Thus, the present study intends to bring out social relationship existing amidst the native South Africans, the Afrikaners or the white South Africans and the people from white authority in apartheid society of South Africa, with specific reference to select novels.
\end{abstract}

Design/Methodology/Approach: The researcher has reviewed almost fifty research articles, fifteen books and fifteen research theses for Master Degree, Master of Philosophy and Doctorate in Philosophy on the novels of Coetzee. Hard copies of some of the books were accessed in the St. Aloysius College library, Mangalore and EFLU library, Hyderabad. The online search was made to collect the database through Google scholar. The studies reviewed are peer reviewed journals, original research papers, National and International Publications. The researcher has referred and followed APA Manuel for the analyses of the research work. Findings/Result: After reviewing a greater number of articles, books and theses it has been found that the multiple interpretations which were given to Coetzee's novels help to emerge his mission which is more quizzical, more explorative. On reading his novels, one may find out that Coetzee does not stop with describing and delineating local situations and characters, but infuses them with universal ideology and characteristics of his mission.

Originality/Value: It's proven that the web of social relationship and social reality are not a fixed presence; it varies from person to person, place to place, culture to culture, and country to country in any moment or situation. Genuine social and human relationship developed and sustained with the true nobleness of humanity is the means to thwart the ills and troubles of the societal conflicts and contradictions.

Paper Type: Analytical research based on review of literature.

Keywords: Apartheid, Boundaries, Colonization, Integration, Imperialism, Oppression, Reconstruction, Relationship 


\section{HUMAN RELATIONSHIP AS THE CRUX OF LIFE :}

Literature plays a very vital role in portraying human life and relationships. It influences people, helps them understand the nuances of every walk of life and leads them to a realization that they need to create, maintain and cherish relationship for ensuing peace and happiness. Of innumerable writers dealing with the theme of human relationship who have taken up the issues of social reality, equality and freedom, John Maxwell Coetzee (J..M..Coetzee 1940) has powerfully depicted the problems of conflicts and contradictions and graphically portrayed the web of human relationship among people of varied races in South African Society. He further explores certain ethical or moral standards to be followed for ensuring social relationship. Coetzee employs postmodern techniques such as 'reflectivity' and 'truth-seeking' to portray the complex relationship and define necessary codes to strengthen cordial relationship [1][2] [3].

\section{SIGNIFICANCE OF THE STUDY :}

The influence of British rule led to South Africa being realized as a nation of the native South Africans or black race, Afrikaners or the white South Africans and the white people of colonial authority. Subsequently, the South African society experienced the hierarchical power structure in which the white colonial authoritative people were on the top of the power position with wealth and dominance, the native south Africans were at the bottom with poverty and unemployment, and the Afrikaners were in the mid-way experiencing 'in betweenness' to both the white people and the native South Africans. The dominance granted to the white authoritative people from the top position gave space for projecting their own culture over the native culture. The native South Africans were meted out torture and oppression from the authority of the white ruling class [4]. In the process, even the Afrikaners or the white South Africans were not spared, as they supported the cause of freedom to the native people. In spite of establishment of nation-sate called Union of South Africa, the National Party being formed and gaining momentum, the rule of 'apartheid' was introduced implicating the separateness among African communities including the whites and non-whites, African and other non-whites, African ethnic groups, and rural African and urban Africans [5] [6]. Therefore, the individuals who were oppressed became restless and staged strikes, boycotts and demonstrations under the guidance of African National Congress (ANC). Their goal was to set up a non-racial alliance, bring to an end apartheid and generate a non-racial democracy. Even so, the task was not that easy as there was no unity, meaningful communication and healthy relationship among the non-European communities. Despite all these movements, it was a complete struggle among the Africans until the apartheid was ended with the reconciliation initiated by the release of Nelson Mandela who was democratically elected President of South Africa [7]. It is in this context, the present study of portrayal of human relationship among the different community people and standards set to sustain such relationships by Coetzee assumes greater importance [8] [9].

\section{METHODOLOGY :}

The researcher has reviewed almost fifty research articles, fifteen books and fifteen research theses for Master Degree, Master of Philosophy and Doctorate in Philosophy on the novels of Coetzee. Hard copies of some of the books were accessed in the St. Aloysius College library, Mangalore and EFLU library, Hyderabad. The online search was made to collect the database through Google scholar. The studies reviewed are peer reviewed journals, original research papers, National and International Publications. The researcher has referred and followed APA Manuel for the analyses of the research work.

\section{OBJECTIVE OF THE STUDY :}

The objective of the study is to undertake a secondary literature review and present summarized data on the depiction of the problems due to conflicts and contradictions and graphic portrayal of the web of human relationship among people of varied races in South African and Russian society. Further, review has been made to collect data on the way the studies have explored certain ethical or moral standards to be followed for ensuring social relationship, ascertain the research implications and determine the research gap on which the present study is made. 


\section{LITERATURE REVIEW :}

Post-colonial era after the colonization of British and other Eurocentric imperialist rule gave rise to the expression of the experiences from the periphery. Many of these writers were not only artists but also political activists. Their writings are naturally concerned with the political and social conditions of the people. It is true that a sense of elation remained in the mind of people during the independence and the sense of hope and freedom found their space in much of early post-colonial writings [10]. However, during the subsequent years, African nations struggled to rejuvenate long subdued mindset of the societies. The writers of post-colonial Africa set about to reflect the state of apprehension and disgust of their countries' sufferings following decolonization, and their writing time and again is permeated with a sense of anguish, melancholy and fury, at both the state of their nations and the leaders who replaced former colonial persecutors [11] [12].

During the closing years of the apartheid epoch and subsequent transition to democracy, South African literature became eminent all over the world. Authors were keen and answered to the long-lasting political agitation, anxiety and its intense consequences on the people of the country. They chronicled or satirized state-enforced racism and investigated the probability of aversion and reluctance. Literature that clasps these affairs has assisted to form definitions of ethnic identity and national integration. Apartheid and post-apartheid literature have political narratives bringing about a keener observation on the matter of human relationship. Racism and its complex reality described in postmodernist techniques became an increasing attention of in South African novels. In addition, the social reality particularly human relationship was a matter of deep concern for the writers of the native South Africans and the Afrikaners or the white South Africans during apartheid and post-apartheid era [13].

\subsection{Identity of the Native:}

Some of the compatriots of Coetzee had greatly influenced his thoughts and ideology. Reviewing some of them would provide the researcher to clarify the issue of ethical code and social relationship in the select novels of Coetzee. The works by Langenhoven (1873-1932), an Afrikaner writer who was best known for his short stories, poems and the translation of Rubaiyat of Omar Khayyam were concerned with the struggle for the official recognition to be given to the native Africans and Afrikaans as their official language. His well acclaimed work is the original South African Anthem, Die Stem (The Voice or The Call of South Africa) written in 1918. Similarly, Jonker (1933-1965) had served in apartheid era using her poetry in Afrikaans language which has also been translated into many other languages. She was championing the cause for human rights and democracy in South Africa. Her best-known published poetic works are Ontvlugting (1956), Rook En Oker (1963), Kantelson (1966), Versamelde Werke (1975), Collected Works (2001) and Black Butterflies (2007). Her poetic works dealt mostly with the pain of the people for freedom and rights, children of black people, repression and the law in apartheid South Africa, government and national orders. On the other, Heerden's (1954-) works dealt with many of the issues of black and other coloured people and their sufferings. In his work, Toorberg (English: Ancestral Voices 1989), he described the details about the exile of the writers and mythological part of South Africa's deep interior in the landscape of his mind [14].

Brink, A. (1935-2015) is an Afrikaner novelist and activist in anti-apartheid movement. His early novels such as, Rumours of Rain (1978) and A Dry White Season (1979) were especially concerned with apartheid and his recent works such as, Before I Forget (2004) and The Blue Door (2006) engaged with the range of issues posed by life in a democratic South Africa [15]. Bessie Emery Head (1937-1986) is the most influential writer from Botswana. She was a well-known contributor to Drum Magazine and also involved in Pan-Africanism. She was well known for her novels such as, When Rain Clouds Gather (1968) and A Bewitched Crossroad (1984). Her works are based on ordinary and humble life of people, mostly with religious touch of Christianity and Hinduism. Gordimer, N. (1923-2014), a South African writer, political activist, member of African National Congress, anti-apartheid movement and of the recipient of the 1991 Nobel Prize for Literature produced novels such as, Burger's Daughter (1979) and July's People (1981) that dealt with moral and racial issues, particularly apartheid in South Africa and created an impact on Coetzee. She has recently been active in HIV/AIDS causes. Her works also dealt with the theme of intimacy and party politics, in particular race in South Africa. Very often she has questioned power relations and the accuracy of truthfulness, Gordimer tells the stories of common men, disclosing moral ambiguities and choices. Fugard, A. (1932-) is well acclaimed for his political 
plays that objected the South African system of apartheid. His works such as, Blood Knot (1961) and Master Herold and the Boys (1982) also demonstrate political injustice, oppositions, boycotts, personal issues, and the issues of racism.

\subsection{Effects of Racism and Colonial Oppression:}

J. M. Coetzee, considered as one of South Africa's most committed, celebrated writers, probes into the themes of racism and colonial exploitation in his writings. The writings condemn the atrocities and oppositions that are connected and associated with the South African policy of apartheid, Coetzee writes from a political view point that extends beyond geographic and social boundaries to attain universal importance. The end result is intensified employing literary devices such as allegory, unreliable narrators, and enigmatic symbolic settings.

All his novels have been published since his return to South Africa and many of them are concerned with the life and relationship of people. Coetzee's novels written up to 1993 may be described sequentially as beginning with: "aggressive imperialist violence in Dusklands followed by a settlement of uncertain standing and duration in, In the Heart of the Country. A defensive phase of anticipated revolution is presented in Waiting for the Barbarians, and there is a stage of open civil warfare in Life and Times of Michael K. Foe departs from the sequence but is no less concerned with questions of power and authority and colonialism" (Attwell, South 14).

Similar claim and portrayal of the events in South Africa could be seen in his novels written after 1993. $\mathrm{He}$ is a writer of postmodern era, but not involved with any nationalized or world movements. In his early novels, Coetzee described the life, relation and situation of the native South Africans, the Afrikaners or the white South Africans and the people from the colonial authority in the apartheid society of South Africa through the use of postmodern elements. Coetzee's novels focus on underprivileged and abused characters. His interest in injustice stems from social and political oppression in South Africa. Coetzee's novels extend beyond the geographic and social boundaries of his native country to encompass universal themes and characters [16]. He combines elements of allegory and fable with an understated prose style and a political narrative view point, projecting a world where an offence against an individual becomes an offence against humanity.

J.M. Coetzee: A Writing in Life (2010) was the first authorized biography of the South African writer, JM Coetzee by the late Afrikaans literary critic, Kannemeyer, who breathed his last soon after completing the book in 2010. It was first written in Afrikaans and translated into English by Michiel Heyns, which was published in the year 2012. The book that gives the readers the graphic account of Coetzee's life, struggles, oppressions and achievements could be taken as a backdrop for his moorings expressed in his novels [17].

Coetzee's Dusklands (1974) is a write up, a critique of the brutality, savagery innate in the colonialist and imperialist mentality of the Western world. In the Heart of the Country (1977) dwells deep into the complex relationship that is formed between the colonizer and the colonized. Waiting for the Barbarians (1980) is the story about the life and struggles of native the South Africans for freedom to rule their land by themselves who were considered as the 'barbarians' by the white authority or the 'Empire' [18] [19]. Life and Times of Michael K (1983) is about the life and journey of Michael K. The novel also depicts the situation of South Africa, in the time of imaginary civil war, during apartheid movement [20]. Coetzee's novel Foe (1986) is woven around the existing plot of Robinson Crusoe by Daniel Defoe. It focused primarily on themes of language and power [21]. In Age of Iron (1990), Coetzee portrays a picture of social and political disaster in South Africa devastated by racism and brutality [22]. The Master of Petersburg (1994) is an illusionary work but specifies the Russian writer Fyodor Dostoyevsky as its protagonist. A work that's profound that affects the life of Dostoyevsky, the life of the author and the history of Russia giving rise to deeply perplexed results [23]. This novel also is based on an event from Coetzee's own life- the death of his son at the age of twenty-three in a mysterious accident [24].

Coetzee's post-apartheid novel Disgrace (1999) is about the sexual abuse of a coloured university student Melanie Isaacs by her professor of romantic course, David Lurie, followed by the rape of Lucy, the daughter of David Lurie by three black strangers. His next novel Elizabeth Costello (2003) is the 
story of Elizabeth Costello, an aging Australian writer, travelling all round the world and narrating issues related to the lives of animals and literary censorship. Slow Man (2005) is concerned with the man who should compromise despite losing a leg in a road accident. Diary of a Bad Year (2007) consists of essays and musings alongside diary entries. The Childhood of Jesus (2013) speaks of immigration. In the new place they are given new names and Spanish is learnt, in their endeavor, to adapt to the new environs [25].

\subsection{Issue of Ethical Reconstruction and Integration:}

A number of research articles, fifteen books and more than fifteen research theses for Master Degree, Master of Philosophy and Doctorate in Philosophy on the novels of Coetzee are found as sources for literature review on Coetzee. Given below are some of the research works that relevant to the study of the web of human and social relationships. Susan Vanzanten Gallagher in her work 'A Story of South Africa: J.M. Coetzee's Fiction in Context' (1991) analysed and found out that the haunting quality of Coetzee's novels comes rather from their denial of conventional ethical models. They are always more or less than the allegories by which they first seem to define themselves with the notion of alterity and also through the construction of the natives as 'others' and white authority as 'self' [26].

Attwell D. in his book J.M. Coetzee: South Africa and the Politics of Writing (1993) proved that the entertaining of banned institutions, the rescue of number of legislative convicts, and speculative compromises concerning the development of democracy. Coetzee's novels have been austere in establishing a feeling of cultural embeddedness. However, the above-mentioned novels have gauged reality beyond their situation as well. They have been successful in awakening the readers to understand the unfulfilled assurance of freedom in its encounter with the cruelty and violence of South Africa [27].

Attridge, D. in his book J.M. Coetzee and the Ethics of Reading: Literature in the Event (2004) does justice to the power and the rewards of Coetzee. Without overlooking the South African dimension of his fiction implicit throughout the book, Attridge has evaluated the ethical impulses and acts that Coetzee tried to propagate through his fiction. In the preview of Jarad Zimbler's book J.M. Coetzee and the Politics of Style published in the month of June, 2014, the author himself said that the book traverses the disclosure of a manner forged in Coetzee's engagement with the problems, difficulties and the complexities of the South African culture and politics, whilst re-examining the nature of Coetzee's indebtedness to modernism and postmodernism. J.M. Coetzee and the Limits of Cosmopolitanism (2013) by Hallemeier, K. found him suffer the limitations of universal comprehension of human fabric. She considers him more subjective and local than universal and all-encompassing [28] [29] [30].

Kharshing, A. in his M.Phil. dissertation, 'Writing the Post-Colonial Self in J.M. Coetzee's In the Heart of the Country and Disgrace' (2005) submitted to EFLU, India, found that, Coetzee explored the predicament of the white complicit-marginalized self while struggling for an ethical reconstruction and integration in a country that rendered all such efforts futile. It also acknowledged the unbridgeable historical constraints of colonialism and apartheid, as well as the constraints of the postmodern decentred and dispersed self in the ethical mission of reconstruction and integration of races. This research also proved that identity of the self is a plural one in the colonized society [31].

Telling Stories: Invasion and Isolation in J.M. Coetzee's in the Heart of the Country and Waiting for the Barbarians' (2008), a project by Solhaug, S. submitted to University of Tromso, Norway proves that the invasion of the white colonial authority is the main reason for the isolation of all the native South Africans during apartheid movement. The researcher also found that Coetzee's narrative master plans give concealed voices life, tell an alternative story of South Africa and make a provision for numerous voices to speak [32].

Bruil, S. in his Ph.D. thesis 'Language as Barrier: Samuel Beckett's Influence on J.M. Coetzee' (2011) submitted to University of Utrecht, Netherlands has established that Coetzee and Beckett seem convinced that language singly in no way empowers them to say precisely what they want to say. For Coetzee, it becomes a valuable factor as well, although in a different, more politically motivated mode. Both have used their own language to express doubt and uneasiness, anxiety [33]. 
5.4 Research Gap:

Having reviewed a number of articles, books and theses other than what is given above, it has been found that the multiple interpretations which were given to Coetzee's novels help to emerge his mission which is more quizzical, more explorative or futile. On reading his novels, one may find out that Coetzee does not stop with describing and delineating local situations and characters, but infuses them with universal ideology and characteristics of his mission. Though he seems to be subjective and focused only on his own perspectives of the events of a particular society, he goes further in telescoping and evolving ethics of social relationship which is universally acclaimed. Hence, the research was narrowed to work on the web of human relationships which has been evolved by Coetzee through his novels while depicting the South African society. He has often used his country's apartheid system and its postapartheid transition to represent the bareness and desolation of human state. In his novels, Coetzee turns an existentialist spotlight on individual behaviour. Coetzee's post-apartheid novel Disgrace described the condition of people after independence and also about Truth and Reconciliation Commission. However, his other novels which were published after the year 2000 are not based on the issues of South Africa. Instead, they expressed the issues of individuality, philosophy and politics worldwide. Hence, the research has been made choosing only J.M. Coetzee's apartheid novels such as, Waiting for the Barbarians, Life and Times of Michael K, Age of Iron and The Master of Petersburg for analyses to prove that the web of social relationship and social reality are not a fixed presence; it varies from person to person, place to place, culture to culture, and country to country in any moment or situation [34] [35].

\section{RESEARCH IMPLICATIONS :}

The research, therefore, intends to bring out social relationship existing amidst the native South Africans, the Afrikaners or the white South Africans and the people from white authority in apartheid society of South Africa, with specific reference to select novels. It, further, focuses how Coetzee analyses the social reality of South Africa and a capitalist society through 'reflectivity' and reveals the reality through 'truth-seeking' ultimately leading to the formulation of the ethics of social relationship among different races such as white people, the Afrikaners and the black South Africans particularly in South Africa during the apartheid movement and also among different classes in a capitalist society which in turn may be universally applicable. In addition, it tries to analyze how Coetzee depicts these problems and arrives at some ethical codes for social relationship. Social relationship between white people of imperialist authority and black people of colonized South Africa enters into convergence and divergence in all a part of their life. In the present study, social relationship is analysed through the reality of South Africa in the universal concept, through Marxist social theory, Pam Morris's concept of realism, Hegelian legacy, Brehm's concept of reactance, Wouter H. Slob's view of truth [36] [37]. The Grand Theory of Karl Marx explaining the conflicts and contradictions in a society and the postmodern devices such as reflectivity and truth-seeking serve as tools for understanding the perspective and mission of Coetzee in depicting the tests and trials of the South African society during the apartheid movement. As an internal device, the term 'reflectivity' is used to denote a reflective distance to the conventional understanding of everything, especially, in the postmodern situation. 'Truth-seeking' may inescapably involve one in paradoxes but in a downright subjectivized truth orientation because of counter-argument to an argument [38] [39].

\section{REFERENCES :}

[1] Chapman, Michael. (2008). The Case of Coetzee: South African Literary Criticism, 1990 to Today. English Studies. South Africa: University of Kwazulu-Natal, 1-23. Print.

[2] Gitzen, Julian. (2013). The Voice of History in the Novels of J.M. Coetzee. Critique: Studies in Contemporary Fiction 35.1 (1993). 3-15. Web. 13 Dec. http://www.tandfonline.com. Print.

[3] Gitzen, Julian. (1988). The Essential Gesture: writing, Politics and Places. Ed. Stephen Clingman, New York: Knopf. Print.

[4] Crossman, Ashley. (2013). Conflict Theory an Overview. Journal of Sociology (2009). Web. 03. Mar. www.formerabout.com. Print.

[5] Meszaros, Istvan. (1995). Beyond Capital: Towards A Theory of Transition. London: Merlin Press. Print.

[6] Morris, Pam. (2003). Realism. Oxon: Routledge, Taylor and Francis Group. Print. 
[7] Deng, Chiou-Dung. (2007). The Enigma of the Other: J.M. Coetzee's Life and Times of Michael K. Schuylkill Graduate Journal. State University of New York at Buffalo. Print.

[8] Poyner, Jane. (2006). J.M. Coetzee and the Idea of the Public Intellectual- Introduction. Modern Fiction Studies. Athens: Ohio University Press. 246-253. Web. 18 Jan. 2012. http://www.ohioswallow.com. Print.

[9] Poyner, Jane. (2006). Introduction. World Literature Journal, 4(5), 1-20.

[10] Attwell, David. (1993). J.M. Coetzee: South Africa and the Politics of Writing. Berkeley, Cape Town: University of California Press. Print. Web. 13 June 2012. http://ark.cdlib.org/ark:/13030/ft5k4006q3/

[11] Marais, Mike. (2012). Little enough, less than little: nothing': Ethics, Engagement, and Change in the Fiction of J.M. Coetzee. MFS Modern Fiction Studies, 46(1), 159-182.

[12] Ransome, Paul. (2006). Social Theory. New Delhi: Rawat Publication.

[13] Gaines, Ernest James. (1971). The Autobiography of Miss. Jane Pittman. New York: The Dial Press. Print

[14] Lin, Lidan. (2001). J. M. Coetzee and the Post-Colonial Rhetoric of Simultaneity. International Fiction Review, 28.1-2. Fort Wayne: Indiana University, Perdue University. Print

[15] De Kock, Leon. (1987). Literature, Politics and Universalism: A Debate between Es'kia Mphalele and J.M. Coetzee". Journal of Literary Studies, 3(4), 35-48.

[16] Durrant, Samuel. (2005). The Invention of Mourning in Post-apartheid Literature. Third World Quarterly, 26(3), 441-450.

[17] Coetzee, J. M. (1980). Waiting for the Barbarians. Great Britain: Secker and Warburg, Print.

[18] Gallagher, S. V. (2012). Torture and the Novel: J.M. Coetzee's Waiting for the Barbarians. Contemporary Literature, 29(2), 277-285.

[19] Moses, Michael Valdez. (1993). The Mark of Empire: Writing, History, and Torture in J.M. Coetzee's Waiting for the Barbarians. Kenyon Review, 15(1), 115-127.

[20] Coetzee, J. M. (1983). Life and Times of Michael K. Great Britain: Secker and Warburg, Print.

[21] Kehinde, Ayo. (2012). Ability in Disability: The Empowerment of the Disabled in J.M. Coetzee's Life and Times of Michael K. African Study Center. Mumbai: University of Mumbai, (2010): 1-32. Web. 18 Aug. http://africanstudies.org. Print.

[22] Gordimer, Nadine. (1984). The Idea of Gardening, The Review of Life and Times of Michael K by J.M. Coetzee. The New York Review of Books, 26(1), 1-6.

[23] Pawlicki, Marek. (2010). Embracing the unknowable. Suffering and death in J. M.Coetzee's Age Iron. In Challenging Evil: Time, Society and Changing Concepts of the Meaning of Evil (pp. 99106). Brill.

[24] Coetzee, J. M. (1994). The Master of Petersburg. Great Britain: Secker and Warburg. Print.

[25] Faber, Alyda. (2013). The Post-Secular Poetics and Ethics of Exposure in J.M. Coetzee's Disgrace. Literature and Theology, 23(3), 303-314.

[26] Attwell, David. (1990). The Problem of History in the Fiction of J.M. Coetzee. Essays on South African Literary Culture. Ed. Martin Trump. Athens: Ohio University Press. Print.

[27] Attwell, David. (1992) ed. Doubling the Point: Essays and Interviews. Cambridge, Mass: Harvard Univ. Press, Print.

[28] Attridge, Derek. (1994). Literary Form and the Demand of Politics: Otherness in J.M. Coetzee's Age of Iron. Aesthetics and Ideology. Ed. George Levine. New Vrunswick: Rutgers University Press, 243-263. Print. 
[29] Attridge, Derek. (1994). Ethical Modernism: Servants as Others in J.M. Coetzee's Early Fiction. Poetics Today, 25(4), 653-671.

[30] Attridge, Derek. (2010). To speak of this, you would need the tongue of a god': On Representing the Trauma of Township Violence. Porto Alegre, 1(2), 3-27.

[31] Baral, Kailash C. and R. Radhakrishnan. (2009). eds. Theory after Derrida Essays in Critical Praxis. New Delhi: Routledge Taylor and Francis Group. Print.

[32] Chesney, Duncan McColl. (2008). Towards an Ethics of Silence: in Life and Times of Michael K. Criticism, 49(3), 307-325.

[33] Clayton, Cherry. (1994). White Writing and Post-Colonial Politics. ARIEL, 25(4),154167.

[34] Coetzee, J.M. (1990). Age of Iron. Great Britain: Secker and Warburg. Print.

[35] Craps, Stef. (2007). J.M. Coetzee's Waiting for the Barbarians and the Ethics of Testimony. English Studies, 88(1), 59-66.

[36] Rasmussen, David M. and James Swindal. (2010). Eds. Sage Masters in Modern Social Thought Habermas II. Vol 1. London: Sage Publication Ltd. Print.

[37] Rasmussen, David M. and James Swindal. (2010). Eds. Sage Masters in Modern Social Thought Habermas II. Vol 2. London: Sage Publication Ltd. Print.

[38] Scanlan, Margaret. (1997). Incriminating Documents: Nechaev and Dostoevsky in J.M. Coetzee's The Master of Petersburg. Philological Quarterly, 96, 463-477.

[39] Slob, Wouter H., (2002). Dialogical Rhetoric an Essay on Truth and Normativity after Postmodernism. Boston: Kluwer Academic Publishers. Print.

$* * * * * * * *$ 